\title{
Limiares: Histoire(s) du cinéma de Jean-Luc Godard
}

Henri Gervaiseau

Escola de Comunicações e Artes - ECA/USP 


\section{Resumo}

Neste artigo apresentamos a série vịdeográfica Histoire(s) du cinéma, de Jean Luc Godard, apontamos as suas principais características, e efetuamos um primeiro exame da ordenação dos seus dois primeiros episódios. Discutimos de que modo Godard estabelece, nesta obra, uma trama poética de relações entre a história do século XX, a história do cinema e a sua própria estória enquanto sujeito enunciador.

\section{Palavras-chave}

Godard, memória, história, cinema, século XX, poética

\section{Abstract}

This article provides an introduction to the video series Histoire(s) du cinéma de Jean Luc Godard, explaining its main features and looking in more detail at the first two episodes. We discuss how Godard establish, in this work, a poetic web of relations between the history of XX century, cinema history and his own story, as enunciator.

\section{Key words}

Godard, memory, history, cinema, XXth century, poetic 


\section{A série}

través de uma recomposição fragmentada da trajetória de
sua memória, o objetivo centrál de Godard quando da
elaboração do projeto da série Histoire(s) du cinéma ${ }^{1}$ parece ter sido o de instituir, simultaneamente, uma memória da história do cinema e uma legenda do século, produzindo um conjunto de ensaios audiovisuais que traduzam a passagem do tempo, sempre relacionando seu discurso às práticas e aos dispositivos técnicos próprios da sétima arte.

Numa primeira aproximação poderíamos dizer que a elaboração de uma trama de relações entre a história do século XX, a história do cinema e a do sujeito enunciador constitui a base primeira do projeto $^{2}$. De modo mais preciso, a sua base fundamental é a elaboração de uma série de relações entre a memória do indivíduo Godard, a memória da geração de cineastas da Nouvelle Vague ao qual pertenceu, e a memória das gerações de cidadãos europeus que

1. Histoire(s) du cinéma é composto por oito episódios, que vieram à luz progressivamente: os episódios 1A (Toutes les histoires) e 1B (Une histoire seule) em 1989; os episódios 2A (Seul le Cinéma) e 2B (Fatale Beaute) em 1994; os episódios 3A (La monnaie de l'absolu) e 3B (Une vague nouvelle) em 1996; os episódios 4A (Le contrôle de l' univers) e 4B (Les signes parmi nous) em 1998. $\mathrm{Na}$ nossa tese de doutorado, ainda inédita, evocamos cada um dos demais episódios que compõem a série, e procedemos a uma análise detalhada da articulação das diferentes matérias de expressão que compõem o ultimo episodio, Os signos entre nós (Gervaiseau, 2000).

2. Como nos parece importante diferenciar a figura poética do enunciador do indivíduo que a encarna, designaremos, na maior parte do tempo, o indivíduo Jean-Luc Godard, autor e diretor da série, mas também o cineasta célebre, assim como os seus porta-vozes, por esta simples palavra: o enunciador. 
viveram e sofreram, no século $X X$, a odisséia da utopia da emancipação social e política da humanidade e foram profundamente marcados pelo trauma histórico do holocausto.

Ao situar seu projeto na fronteira entre história e memória, Godard optava por trabalhar no limiar do esquecimento e da lembrança e buscava exprimir uma experiência do tempo que se dá, como dizia Benjamin, num instante presente onde toda a temporalidade encontrase repentinamente implicada e, deste modo, de mostrar as superposições e os saltos temporais propôs a experiência da rememoração ${ }^{3}$.

Leitor atento de Bergson e cineasta, ele sabia que a sobrevivência das imagens é a condição de possibilidade da memória, e que esta sobrevivência, a sobrevivência latente das marcas psíquicas de uma impressão vivida dentro da memória, permite o reconhecimento, ato concreto pelo qual apreendemos o passado no presente, ato mnemônico por excelência que vem coroar o trabalho de busca (anamnese) ou de reencontro casual com o passado (reminiscência). Ele sabia, em outros termos, da ligação intima existente entre a memória e as imagens que constituem o seu conteúdo e fazem ressurgir o tempo ${ }^{4}$.

Buscava, por isso mesmo, trabalhar no limiar dos traços materiais (os fotogramas) e dos traços psíquicos (as imagens imateriais que formam o conteúdo da nossa memória), e subseqüentemente, de tirar partido do papel estratégico da imagem de base fotográfica enquanto suporte de rememoração, enquanto traço material da presença efetiva, no passado, de seres hoje ausentes.

Eis porque buscava, também, como apontou Bergala, produzir uma imagem de nova natureza que, depois de uma dolorosa passagem pelo esquecimento, pudesse ressurgir, no presente, e, se comunicar, neste ato, com um instante passado. Esta imagem deveria, além disso, no curso da série, poder ser repetida, e remeter, a cada vez, a uma

3. Retomamos, num outro contexto, a idéia deste tipo de experiência do tempo a W.Benjamin (ver Lissovski, 1998, p. 96).

4. Retomamos aqui observações de Macron e de Ricoeur sobre o pensamento de Bergson (Macron, 2000; Ricoeur, 2000, pp. 32-47). 
nova configuração temporal, a um novo modo de inter-relacionamento do presente, do passado e do futuro (Bergala, 1999).

O holocausto, momento axial que impõe o dever de memória, constituiria o núcleo memorial central da série, em torno do qual se condensaria um conjunto de questões que diz respeito tanto à história do cinema e à memória do cineasta (relação entre realidade e ficção) quanto aos temas candentes da atualidade (conflito entre israelenses e palestinos, guerra da Bósnia).

A série de ensaios projetada devia ter a dimensão de uma verdadeira epopéia. A exemplo da epopéia, a série deveria celebrar um conjunto de tradições perdidas do mundo do cinema, evocar um complexo de representações sociais, políticas e religiosas às quais o mundo da história do cinema foi ligado - cada episódio combinando, em graus diversos, elementos míticos, lendários, históricos. A série deveria também favorecer uma reflexão crítica sobre esse mundo e propor, nesse contexto, um código moral, uma estética. A epopéia projetada constituiria, por outro lado, uma legenda das vitimas, uma memória do sofrimento dos vencidos da história do século $\mathrm{XX}$, as vitimas de Auschwitz sendo, na série, os delegados, por excelência, de todas as vitimas desta história, pela própria singularidade do extermínio planificado de todo um povo, que atinge o elo de solidariedade entre o gênero humano ${ }^{5}$.

No curso da série o enunciador, a semelhança do narrador da epopéia, deveria relacionar os eventos evocados com a sua experiência. As estórias relatadas pelo enunciador, grande ancestral, permitiriam estabelecer uma ponte entre a memória e o passado histórico. Através da imagem e da palavra do enunciador, seria possível tecer a rede formada pela multiplicidade de fatos esparsos que todas as estórias contadas evocariam. Ao tentar dar conta de uma constelação de eventos, o enunciador buscaria demonstrar os seus encadeamentos, articulando, no curso da série, temporalidades heterogêneas, de curta e de longa duração. Neste quadro, alguns dos

5. Sobre esta interpretação da Shoah, ver Alencastro (2000). Sobre a preservação da memória do sofrimento dos povos e as vitimas de Auschwiz como delegados junto a nossa memória das vitimas da história ver Ricoeur (1985). 
eventos evocados revestiriam uma dimensão de sintoma de pontos de ruptura, de brusca ou lenta deterioração de fenômenos históricos de longa duração ${ }^{6}$.

Os traços materiais que constituem os fotogramas dos filmes produzidos no curso da história do cinema, autênticos vestígios do passado, funcionariam como índice, como prova dàs relações de acontecimentos estabelecidas pelo enunciador. A relação estabelecida entre estes vestígios e o mundo ao qual pertenciam permitiria, além disso, uma figuração do contexto social e cultural deste mundo ${ }^{7}$.

Tratava-se, em última instância, para Godard, de promover o encontro de um conteúdo semântico com uma forma poética para exaltar a força central do cinema como lugar de memória redentor capaz de esclarecer desafios do tempo presente. $\mathrm{O}$ canto que a série comporia devia poder tornar-se uma espécie de dádiva do sujeito enunciador ao mundo do cinema - ao qual ele pertence - tendo em vista a instauração de uma harmonia nova para ele e para coletividade virtual constituída pelos espectadores de cinema ${ }^{8}$.

A forma de abordagem escolhida, que trabalha de forma deliberada e consciente a ambigüidade da posição do sujeito produtor de um saber sobre seu objeto deve, para Godard, ser associada a uma postura poética, em que, através do eu de um sujeito singular, é feita uma reflexão sobre a relação essencial de cada um no mundo.

O enunciador seria, na série, um ser sensível e pensante, que exteriorizaria, pela palavra, pensamentos e emoçỗes: Através do percurso que a multiplicidade dos discursos enunciados desenhariam, o enunciador das Histoire(s) estaria em busca de si mesmo, estando em jogo o estabelecimento da sua identidade no tempo, no limiar da história do século XX e do cinema.

A postura poética evocada tem por pressuposto uma colocação em evidência do que os signos têm de palpável, de sensível e a procura de um ritmo próprio à expressão de suas combinações. A

6. Sobre a integração narrativa entre evento, conjuntura e estrutura ver Ricoeur (2000), pp. 307-320.

7. Sobre a relação entre vestígio e figuração ver Ricoeur (1985), p. 335.

8. Retomamos aqui, em outro contexto, considerações de Revel sobre a epopéia como dádiva do sujeito enunciador (Revel, 1998). 
obra poética que Godard se propunha criar devia então poder funcionar como uma totalidade de relações complexas em que cada elemento contribui para a significação, seja da ordem do escrito, do falado, do sonoro e do visual, através um cruzamento incessante desses diferentes materiais e de um referimento constante de cada um desses elementos ao outros, a fim de assegurar a coerência e o dinamismo do conjunto 9 .

Uma gama muito rica de interpretações de cada episódio, e no interior de cada segmento de cada episódio, devia ser tornada possível, em função do recurso a uma forma de composição dos fragmentos caracterizada por uma grande polifonia semântica. Se uma grande liberdade devia presidir à reunião sucessiva e/ou simultânea dos diferentes materiais de expressão utilizados, e se o objetivo da reunião podia corresponder a finalidades heterogêneas, tanto de ordem semântica quanto de ordem mais propriamente rítmica ou emocional, todavia o jogo das inter-relações seria raramente gratuito.

Se não devia haver aí a institucionalização de um sentido unívoco para cada segmento e se, muito pelo contrário, os sentidos deviam se escalonar, como em toda obra poética, o leque de significados a propor não teria por objetivo afirmar sua equivalệncia generalizada. Seu objetivo seria sobretudo, através da progressão gradativa necessária ao desenvolvimento da obra, compor algumas propostas semânticas mais importantes, deixando livre curso à expressão de suas nuanças as mais delicadas. Nesse contexto, o espectador seria levado a decifrar essas propostas, através do entrelaçamento progressivo das cadeias de significações.

Observemos que em função da extrema densidade da composição dos segmentos que constituiriam cada episódio, foi previsto o recurso constante, na série, a uma grande variedade de meios mnemotécnicos. Os mais próximos dos utilizados nos textos poéticos sendo, certamente, o retorno regular de sonoridades, de palavras, de associações de palavras ligadas ao próprio título da série: Histoire(s) du cinéma.

9. Retomamos aqui, em outro contexto, uma série de considerações de Aquien sobre a linguagem poética (Aquien, 1996, pp. 424-430). 
O mais importante princípio poético da série devia consistir, como disse o próprio Godard, em "aproximar coisas que até então nunca tinham sido aproximadas nem pareciam passíveis de aproximação"10.

A aplicação desse princípio poético encontra-se no centro da elaboração do projeto ${ }^{11}$. Antes de explicitar o porquê, convém apontar brevemente a particularidade e a grande diversidade dos materiais utilizados.

Ao lembrar os métodos de trabalho de Godard durante a realização da série, Jean Douchet se refere com humor à existência de um "bando das quatro" fitas, que define: 1) "a que mantém a fita de imagens"; 2) "“a que entrega as palavras"; 3) a que "transporta os barulhos"; 4) a que "se reserva à música" (Douchet, 1998, p. 30-31).

É entre essas quatro fitas que, após uma seleção, deviam ser distribuídos os materiais pacientemente coletados no curso dos longos anos de amadurecimento do projeto. Tentemos estabelecer uma relação, indicativa e sintética, dos materiais selecionados para cada uma dessas fitas.

$\mathrm{Na}$ fita das imagens dos diversos episódios da série, podem figurar:

1) imagens extraídas: dos mais diversos filmes de ficção, de documentários, de noticiários, de filmes de família, de filmes pornográficos. Notemos, com Bergala, que foi necessário, para Godard "comprar, registrar, percorrer milhares de fitas de vídeo para levar a cabo a sua série", para reencontrar os planos que

10. Esta frase aparece escrita na tela no curso do episódio IV A (Les signes parmi nous). Phillipe Forest lembra que André Breton, no Manifesto Surrealista de 1924, citando o poeta francês Pierre Reverdy, "evoca essa 'luz da imagem' que nasce da aproximação como que fortuita de dois termos ou 'realidades distantes'. A imagem é uma criação pura do espírito. Ela não pode nascer de uma comparação, mas de uma aproximação de duas realidades mais ou menos distantes. Quanto mais distantes e justas forem as ligações das duas realidades, mais a imagem será forte - mais ela terá poder emotivo e realidade poética" (Forest, 1998, pp.18-19).

11. Para uma análise detalhada de diversas modalidades concretas de aplicação deste principio na organização da alternância dos planos do episódio 4.B. (Os signos entre nós), ver Gervaiseau (2000). 
não se encontravam disponíveis para a convocação na sua memória voluntária, já que "na sua memória do cinema, como em qualquer memória, há muito mais informações virtualmente disponíveis do que informações acessíveis". Foi preciso então, para Godard, "contar em parte com o acaso (ou.o pré-consciente, mas é às vezes a mesma coisa) para encontrar o plano do qual precisava, com o sentimento que ele se encontrava, sem dúvida, em algum lugar, mas como uma agulha no palheiro". Bergala observa que o modo de aparição das imagens do passado se dá, na série, sobre o fundo negro de volta das imagens na memória involuntária: Como lembra Bergala, o próprio Godard declarou que somente após ter terminado o conjunto da série, ele percebeu o retorno constante de alguns planos, como se, observa Bergala, "o trabalho da memória inconsciente tivesse predominado sobre a sua preocupação em controlar rigorosamente o 'tempo de antena' de cada cineasta convocado na série" (Bergala, 1999, p. 141). Praticando, no curso da realização da série, o exercício da memória involuntária, Godard parece compartilhar a crença de Proust segundo a qual o passado pode encontrar-se escondido "em um . objeto material qualquer, fora do âmbito da inteligência e do seu campo de ação. Em qual objeto, isso não sabemos. E é questão de sorte se nos deparamos com ele... ou se jamais o encontramos." (Proust, apud Benjamin, 1991, p.106).

2) reproduções de fotografias e de quadros célebres e anônimos;

3) atores e atrizes especialmente convidados pelo cineasta, que dizem trechos de diversos textos selecionados e algumas vezes, mais simplesmente, meditam ou andam no intervalo entre duas leituras;

4) imagens do próprio cineasta, apoiado às prateleiras de sua $\because$ biblioteca, retirando livros, dos quais consulta as capas e folheia páginas; ou trabalhando à mesa de montagem ou; ainda, mais simplesmente, sentado e pensativo, charuto à boca; : '.

5) além disso, podem coexistir, sobre essa mesma banda, diversas imagens através de efeitos de mixagem e de sobreimpressão, assim como inscrições verbais: títulos de filmes, de romances, trocadilhos, notas.musicais, palavras de ordem, expressões consagradas, palavras atrofiadas, trechos de críticas cinematográficas, etc. 
Na fita "que entrega as palavras" dos diversos episódios da série, podemos ouvir: a voz do realizador, de atores e atrizes e de diversas outras pessoas que lêem trechos de poemas (Eluard, Baudelaire, Valéry, Rimbaud, Pound, etc); de romances (Faulkner, Duras, Bernanos, etc.); contos (Borges); obras de filosofia (Wittgenstein; Heidegger, Foucault, etc); de peças de teatro (Beckett, Shakespeare etc); de epopéias (Homero); de estudos e ensaios históricos, literários, sociológicos e outros (Braudel, Benjamin, Péguy, Blanchot, etc); de canções (Ferré, Ibañez, Cocciante etc); de estudos de história da arte (Faure, Malraux etc); de artigos e ensaios sobre a arte cinematográfica (Bazin, Epstein, Bresson, Rosselini etc); de enunciados científicos (J. Ort); de diálogos de filmes sem os filmes; de entrevistas e depoimentos de cineastas (Ophuls, de Oliveira, Renoir); de trechos de trechos de conversação; etc.

Na fita que "transporta os barulhos", pode-se ouvir: 1) barulhos de vozes humanas: gritos de desespero, sussurros; etc; 2) sons da natureza: o barulho do trovão, do raio, do vento, da água que cai ou que corre, etc; 3 ) sons e barulhos de objetos produzidos pelo homem: sons de sinos, de buzinas, de metralhadoras, de bombas, de máquina de escrever, de bobinas de filmes girando em uma mesa de montagem, etc.

Na fita "que se reserva à música", podemoś ouvir: 1) canções clássicas, populares ou de variedades; 2) música clássica e contemporânea.

Como vemos, a obra composta pela série foi estruturada com base em uma grande quantidade de fragmentos de obras, de materiais tangíveis e cotidianos, conjunto de coisas que até então nunca haviam sido aproximadas nem pareciam passiveis de aproximação.

Qual foi o princípio mais importante que comandou a combinação dessas quatro fitas - entre as quais, como bem viu Douchet, tratava-se de criar um vai-e-vem constante, em forma de interferências, de ressonâncias e de repercussões? (Douchet, 1998).

Parece, em primeiro lugar, que um papel essencialmente rítmico e emocional foi destinado à fita "que transporta os barulhos" 
e à parte instrumental da fita que "se reserva à música". Parece, em segundo lugar, que a produção das proposições semânticas mais importantes das quais falamos anteriormente foi tornada possível, no essencial, por meio da combinação da fita de imagens com aquela que "entrega as palavras", embora uma dimensão rítmica e emocional de primeiro plano esteja também presente na apresentação dos materiais dessas duas fitas.

Mas, poderíamos nos perguntar, como a combinação de um mosaico de citações de obras escritas e de uma grande quantidade de fragmentos de obras pictóricas, fotográficas, cinematográficas, televisivas, etc, pôde, progressivamente, constituir o discurso audiovisual da série?

Parece-nos que a empreitada se tornou possível pelo fato de que Histoires(s) du Cinéma, ensaio crítico de um novo gênero, relato odisséico da travessia de um mundo originário, história de uma memória, é uma obra em que a palavra do sujeito enunciador - como acontece na epopéia - desempenha um papel de primeiro plano.

Os textos ditos em voz alta pelo enunciador e por seus portavozes, quer se trate de trechos escritos por terceiros ou redigidos pelo próprio realizador, não são apresentados como tais ao longo da série. Por meio do retorno da voz no texto (Certeau, 1987, p.177) dos enunciados, essas inumeráveis citações textuais se encontram de súbito metamorfoseadas, imersas no presente que o ato enunciativo instaura.

Nesse contexto, as imagens, qualquer-que seja sua origem, fazem figura de passado, e é a exploração das relações existentes entre essas imagens do passado e as palavras proferidas no presente da enunciação que permite estabelecer novas proposições semânticas.

Assim, para Godard, no contexto da série, uma imagem montável não é apenas - como indicou Aumont - uma imagem "que comporta pelo menos um aspecto pelo qual ela vai poder entrar em relação com outras". Ela deve também poder comportar pelo menos um aspecto pelo qual vai poder entrar em relação com uma palavra e assim conter "uma reserva virtual que não se esgota no que ela 
comunica ou exprime". Como observou judiciosamente Aumont, assim compreendida a montagem se torna uma atualização desse virtual, um modo de agenciar imagens sonoras e em movimento para fazer surgir o virtual que elas comportavam (Aumont, 1999, p.18).

Até então esse virtual não havia podido se atualizar na medida em que, salientemos, essas imagens sonoras e em movimento nunca haviam sido aproximadas e não pareciam passíveis de aproximação:

Estas imagens e estas palavras ressurgem; como apontou Bergala, desconectadas dos filmes, das estórias, e dos textos dentro dos quais encontravam-se inseridas e vão formar, através da montagem, novas constelações, novos arranjos imprevistos, que correspondem a deslocamentos de intensidade psíquica e temporal inesperados e produzem novos sentidos. Arranjos e constelações percebidas fugazmente que, pela força do seu impacto emocional; intelectual e plástico, permanecem vivas na nossa memória de espectadores e parecem devolver a arte cinematográfica a sua aura perdida.

O reencontro da aura é também a celebração, elegíaca, da memória das vitimas e do sofrimento. Frente ao fracasso das utopias e a constatação da permanência da miséria, "último fundamento da comunidade moderna", não há entretanto, para o neo-humanismo de Godard, resignação, mas celebração da epifania do gesto humano engajado na circunstância, na busca do resgate da camada mais profunda da solidariedade entre os humanos que se procurou aniquilar em Auschwitz.

Nos limites do presente artigo, nos limitaremos a um primeiro exame - introdutório, sintético e indicativo - da ordenação dos dois primeiros episódios que compõem a série, sem nos preocuparmos em produzir, para cada um dos episódios, uma análise específica da articulação das diferentes matérias de expressão, tais como o som e a imagem, buscando oferecer uma primeira compreensão da ordenação e da articulação progressiva dos temas destes dois episódios; bem como identificar, dentro de seu encadeamento, algumas proposições poéticas maiores, observar as retomadas e as passagens temáticas de um episódio a outro. 


\section{Episódio 1A: Toutes les Histoires}

Parece-nos que este episódio introdutório, possui, num primeiro momento, um conjunto de objetivos de ordem geral, São eles: afirmar a existência de uma pluralidade de territórios da história do cinema-todas as histórias; precisar o objeto da série - as histórias que aconteceram; chamar a atenção do espectador para dimensões esquecidas por essa história - exemplo: a história dos filmes que jamais foram feitos; introduzir de forma elíptica temas que serão ulteriormente retomados em outros episódios - exemplo: o cinematógrafo, instrumento de comunicação com o mundo dos mortos (a morte nos faz promessas através do cinematógrafo).

Por outro lado, o episódio 1A possui uma série de objetivos específicos. O primeiro parece ser o de demonstrair a instrumentalização, feita pela indústria de Hollywood - com a chegada de Thalberg à Metro Goldwyn Mayer -, da capacidade do cinema de nos transportar, a baixo custo, para um alhures - "para um mundo que esteja de acordo com nosso desejo" - com vistas a erigir uma espetacular potência de ficção, sem que seja levada em consideração a questão central dos efeitos possíveis dessa potência sobre o mundo real.

O segundo objetivo parece ser o de exaltar, por oposição, através do exemplo do pobre cinema das atualidades produzido durante a Segunda Guerra Mundial, a capacidade singular e única do testemunho do cinema, sua aptidão a tornar visível, sensível, a atualidade da história. Nesse contexto, duas questões centrais são levantadas: da relação do cinema com o mito e a dos efeitos da ficção sobre o real. Como conclusão, é introduzida uma primeira meditação sobre a arte do recolhimento e da expressão dos traços deixados pela História.

No início do episódio, ao surgirem as primeiras imagens, dois enunciados enigmáticos são propostos, parecendo sugerir uma dupla chave de leitura para o espectador: "que cada olho negocie por si próprio" e "não mostre todos os lados das coisas, guarde para si uma margem de indefinição". Na seqüência dessas duas frases, aparece, inscrito diretamente sobre os fotogramas dos filmes que aparecem 
na tela - entre outros: The Band Wagon, La Règle du Jeu, Les Amants Crucifiés, Rancho Notorious -, um dos enunciados centrais do primeiro episódio: "O cinema substitui o nosso olhar por um mundo que esteja de acordo com nosso desejo".

A partir daí, na primeira parte do episódio, Godard se esforça para mostrar - inicialmente através do exemplo de Thalberg - que a indústria do cinema vai rapidamente aproveitar-se da força que o cinema possui de nos transportar para esse outro lugar de encantamento, "porque está de acordo com nossos desejos". O relato logo adquire, como aliás acontecerá com muita frequiência ao longo de toda a série, uma dimensão mitológica e trágica - "a fundação, o pai fundador, o filho único e foi preciso que essa história passasse por aqui [...] para que isso se ponha a existir [...] isso, a potência de Hollywood, a potência da Babilônia."

Notemos que quando a voz em off de Godard diz "a potência de Hollywood", dois breves enunciados, em inglês, aparecem na tela. Depois, quando ele diz "a potência da Babilônia", surge mais um enunciado. Esse três enunciados constituem as citações de slogans criados pela indústria de cinema norte-americana: Trade follow films [O comércio segue os filmes], A film is a girl and a gun [Um filme é uma garota e um fuzil], The world for a nickel [O mundo por um niquel].

Encontram-se assim destacados, inscritos sobre imagens de filmes: a) a importância da indústria do cinema na difusão dos produtos comerciais dos Estados Unidos da América; b) a importância para a indústria do cinema americano das histórias que relacionem 0 sexo (a girl) e a morte (a gun) - temas imbricados aqui, que o enunciador retomará no episódio seguinte, dizendo que as grandes histórias da indústria do cinema foram o sexo e a morte; c) uma das principais razões do imenso sucesso dessa indústria: é o acesso a esse mundo que nos encanta a todos, porque está de acordo com nossos desejos, encontra-se ao alcance da mão, ou antes, do bolso de todos, já que não custa quase nada, apenas um níquel.

Salientemos que a escolha muito precisa de planos em que esses enunciados vêm se inscrever dá, por vezes, uma base quase documental à dimensão mitológica adquirida pela referência à 
potência de Hollywood (igualada à potência da Babilônia). A citação de plano mais significativa, a esse respeito, é a da reconstituição da Babilônia no filme Intolerância de Griffith ${ }^{12}$. É sobre essa imagem que virá inscrever-se a primeira parte do enunciado: The world for a nickel.

No fim do primeiro segmento, dedicado a Thalberg, estabelece-se uma sutil ligação entre a fábrica de sonhos constituída por Hollywood e o cinema soviético dos primeiros tempos; a idéia proposta por esse novo segmento parece ser a de que mesmo o comunismo sonhou em um dia adquirir a capacidade de nos transportar para um alhures.

No caso da URSS - concernida aqui em altíssimo grau -, esse outro lugar é paradoxalmente ligado a um horizonte de esperas e utopias que remetem, em última instância, a necessidades relacionadas à atualidade de sua história, razão pela qual, pouco após o enunciado "uma fábrica de sonhos, e fábricas assim o comunismo esgotou-se de tanto sonhá-las", aparece na tela a expressão vertoviana kino pravda, enquanto escutamos a voz em off de Godard dizer: "história do cinema, atualidade da história, história das atualidades." De imediato, não se dá uma seqüência a esse tema, que só ressurgirá com força na segunda metade do episódio.

Entretanto, notemos que uma das leituras possíveis deste último enunciado, é que a história do cinema é também a da história da emergência da possibilidade de novas formas de presentificação da história.

$\mathrm{Na}$ história do cinema, a forma histórica dessa presentificação foi a das atualidades, categoria de filmes que rapidamente foi instrumentalizada, desde os primeiros anos do cinematógrafo, pelos poderes públicos e pelos políticos, em função de uma gama diversificada de interesses, como já mostramos. Se a força de testemunho dessa nova forma cinematográfica de

12. Numa entrevista concedida à Rádio France Culture, Godard destaca: "no primeiro episódio das Histoires (s), associo a potência de Hollywood à potência da Babilônia. Mas o texto vem após imagens em que se vê a reconstituição da Babilônia para Intolerância. Se não fosse assim, a imagem pemaneceria vaga, pois tornar-se-ia uma fórmula que podemos esquecer." (Bergala, 1988, p. 318). 
presentificação da história foi assim desviada, resta ainda a possibilidade de distinguir essa força, virtual, de suas atualizações, e é que o episódio de Godard, a sua maneira, nos permite melhor compreender, como o veremos.

Após uma nova e elíptica referência à boa estrela do "pai fundador" - "e, além disso, casado com uma das mais belas mulheres da terra" -, um novo enunciado, enigmático, dito pela voz em off, propõe-se à nossa reflexão: "o que passou pelo cinema e conservou uma marca dessa passagem, não pode mais entrar em outro lugar".13. A expressão ém outro lugar liga-se imediatamente à idéia do sonho, e a palavra sonhar vem inscrever-se na tela, sobre o rosto de uma moça de expressão grave. Por sua vez, esta última palavra traz o retorno do tema da potência de Hollywood, através, dessa vez, da evocação de um outro grande produtor, Howard Hughes.

Em seguida, o enunciador retoma, de forma subliminar, o fio de sua intervenção inaugural, na qual ele enfatizava a importância de dizer "todas as histórias [do cinema] que aconteceram", passa bruscamente a um outro tema e evoca, de modo elíptico, uma dimensão esquecida da história do cinema: "todas as histórias dos filmes que nunca foram realizados" - sendo que a referência mais significativa parece ser aqui o projeto do filme de Orson Welles sobre Don Quixote, nunca realizado em razão de inúmeras dificuldades financeiras. Em seguida, faz-se uma alusão sarcástica à difusão dos filmes televisivos - cópias, reproduções ${ }^{14}$.

Subseqüentemente, um novo enigma nos é proposto: "A felicidade não é alegre”, enigma que somos progressivamente levados a decifrar, no decorrer do episódio e da série. Depois, de modo brusco, surge a temática que dominará todo o resto do episódio, se bem que pareça por vezes, de repente, esvanecer em função de muitas

13. Uma das leituras possíveis desse enunciado, baseado no desenrolar do resto do episódio, poderia ser a de que o cinema deixa uma marca inegável na História e que, por sua força de penetração no coração e no espírito das massas, pode tornar-se irreversivelmente um ator maior da História.

14. Aumont salienta, com alguma razão, que para Godard "o reconhecimento da aura cinematográfica está contida na oposição cinema/televisão (aquele que faz erguer o olhar/aquela que faz abaixar os olhos)" (Aumont; 1999, p. 203). 
digressões poéticas. A primeira referência à Segunda Guerra Mundial que surge no texto do enunciador é uma data: "mil novecentos e quarenta". Em seguida, uma série heteróclita de enunciados se liga através da enumeração sucessiva dos anos da guerra: "trinta e nove, quarenta, quarenta e um, quarenta e dois, quarenta e três, quarenta e quatro" e, no fim do episódio, "trinta e nove, quarenta e quatro".

- A primeira data liga-se a um enunciado que estabelece uma relação entre os atores do teatro francês e o avanço do exército alemão. Graças a essa referência ao teatro, introduz-se a idéia de que "o teatro é algo demasiadamente conhecido e que o cinematógrafo é algo demasiadamente desconhecido até agora".

: O retorno subseqüente do enunciado "Históriá do cinema, atualidade da história, história das atualidades", acompanhado de uma imagem de Hitler agitando os braços, sugere que está sendo apresentada uma dimensão desconhecida dessa história, e nos leva ao cerne da temática que evocávamos anteriormente, que é a da relação do cinema com a atualidade de seu tempo, ponto destacado de maneira provocadora por um jogo de palavras que vem.logo em seguida ao enunciado: "histórias do cinema com S, com SS, acompanhado de uma enumeração de datas: trinta e nove, quarenta e quatro".

Uma breve digressão evoca a passagem serena de um outro tempo, o das estações. As palavras "Ó mês de florações" e "Maio que foi sem dor" se inscrevem diretamente sobre reproduções de quadros de Seurat mostrando instantes de lazer na região parisiense, misturados à inscrição do título da série Histoire $(s)$ du Cinéma, situado, subsequientemente, entre duas imagens que remetem a destruições provocadas pela guerra.

Depois, à traição da rádio opõe-se - poeticamente - o engajamento do cinema na discussão dos problemas de seu tempo, através da evocação de filmes (Le Testament du Docteur Mabuse, $M$, Siegfried, Le dictateur) e de um diretor, Lubisch, autor de um filme antinazista, To be or not to be.

Surge então um enunciado central, voluntariamente peremptório, que põe em epígrafe a capacidade de testemunho do cinema de atualidade. "Quarenta, quarenta e um, mesmo marcado 
pela morte, um simples retângulo de trinta e cinco milímetros salva a honra de todo o real"15.

Se a afirmação é peremptória, segundo parece, é porque ela se quer fundadora, ela visa acentuar a importância ética e moral desse fato simples: "ser aí, estar aî" quando for preciso, para que a memória de um instante ao mesmo tempo qualquer e decisivo da história possa inscrever-se na memória dos homens. O enunciador introduz uma das idéias centrais da série, através da associação desse enunciado - envolvendo o conceito heideggeriano de $\mathrm{Da}$ Sein, palavras alemãs que aparecem sobre a tela e que traduzimos como ser-aí - a um simples retângulo de trinta e cinco milímetros que nos mostra, em plano médio, o cadáver estirado no chão de um ser humano desconhecido, com os membros já meio corroídos.

A idéia de que o cinema estava aí encontra-se, imediatamente após, reafirmada: “quarenta e um, quarenta e dois, e se as pobres imagens ainda nos atingem, sem cólera e sem ódio, como faz o açougueiro, é que o cinema está-aí."

Essas "imagens que ainda nos atingem", que testemunham "o que aconteceu", nos mostram, nesse caso preciso, inicialmente, duas moças que vibram de exaltação histérica na passagem dos dignitários nazistas - e, ao que parece, de Hitler -; depois uma tomada em plongée de uma assembléia nazista, e no primeiro plano, a silhueta encravada na sombra de dois braços erguidos, fazendo a saudação nazista, palmas estendidas para frente, imagens provavelmente extraídas de um filme de atualidades.

Um novo plano, mais aproximado, nos mostra o cadáver de um soldado morto, estendido no chão, com o rosto já descomposto, plano associado a uma cena de Metropolis, em que se vê a heroína do filme cercada por crianças. Pode-se ler, no fotograma do filme de Lang, as palavras "na perturbação sagrada" ao passo em que a voz em off exalta, de forma elíptica, o cinema mudo: "o mudo, com sua humilde e formidável potência de transfiguração, quarenta e dois, quarenta e três, quarenta e quatro".

15. Aumont observa, com razão, que no enunciado a honra salva não é somente a do cinema, mas a de todo o real (Aumont, 1999, p. 42). 
Notemos que o uso do adjetivo humilde visa, sem dúvida, salientar que é precisamente porque as imagens são mudas que elas possuem essa formidável potência, levando o espectador a concentrar sua atenção na imagem, a aguçar sua visão, e assim poder melhor perceber a transmutação das figuras que surgem na tela.

Com a ajuda de uma breve referência, o enunciado assume de repente uma dimensão mais assumidamente poética, com o enunciador afirmando que "o que mergulha na noite é a repercussão do que submerge o silêncio, o que submerge o silêncio prolonga na luz o que mergulha na noite", palavras acompanhadas por um plano de Lili Marlene, onde se destaca a cruz gamada de uma bandeira nazista, seguido de um segundo plano que nos mostra o avançar de um tanque no alto do qual emerge a silhueta de um soldado.

Note-se que o tema introduzido aqui dos ecos e das correspondências da noite, do silêncio e da luz - e que será retomado no episódio 4A -, parece designar poeticamente, no presente segmento, o combate que opunha diversas forças no decorrer da Segunda Guerra, sem que a filiação dos adversários a um determinado campo seja explicitada ${ }^{16}$.

O início da parte seguinte do episódio é marcado por um enunciado que vem inscrever-se na tela: "a ficção contra o real". Observe-se, antes de prosseguir em nossa apresentação sucinta do desenrolar do episódio, que essa oposição é, para o enunciador, característica da tradição hegemônica do cinema espetáculo, e que ele exaltará em episódios posteriores da série - em especial nos episódios $3 \mathrm{~A}$ e $3 \mathrm{~B}$ - outras tradições cinematográficas que souberam, contrariamente, "estabelecer uma fraternidade" e uma "igualdade" entre realidade e ficção.

Um segundo enunciado, dito pela voz em off, encontra-se ligado ao que acabamos de comentar: "Imagens e sons, como pessoas que se conhecem na estrada e não podem mais se separar."

16. Além disso, pareceria possivel, através de um exame atento desse segmento, compreender melhor a alusão subliminar feita à problemática do combate entre sombra e luz própria ao expressionismo, posteriormente instrumentalizada pelo cinema nazista. 
A idéia sugerida parece aparentemente simples, mas sua ligação com a seqüência do discurso do enunciador é menos evidente: é no decorrer da história do cinema, em marcha, que imagens e sons se conhecem.

"Para prová-lo,"' prossegue o enunciador, "as massas amam o mito e o cinema se dirige às massas. Mas se o mito começa em Fantômas, ele acaba em Cristo. $\mathrm{O}$ que as massas ouviam ao escutarem São Bernardo pregar? Algo de diferente do que ele dizia. Talvez. Sem dúvida."

Notemos que o enunciador nos entrega apenas a primeira parte de seu raciocínio, que diz respeito à relação do cinema com o mito. O que parece ser sugerido no primeiro segmento do enunciado é o seguinte: uma vez que, inicialmente, as massas amam o mito, e o cinema se dirige às massas, o cinema se organiza para criá-los, retomálos ou mesmo atualizá-los. Em segundolugar, o mito tem um percurso, e este pode desembocar numa tragédia. Em terceiro lugar, há uma hiância entre o enunciado do mito e sua interpretação. Este último ponto, que remete à leitura do mito pelas massas; e portanto ao seu efeito sobre elas, será retomado um pouco mais adiante, como veremos.

Mais do que todos os outros, o seguinte enunciado - "mas como negligenciar o que compreendemos no instante em que esta voz desconhecida mergulha na parte mais profunda de nossos corações?" -, só pode ser compreendido em relação às imagens que o acompanham e à sequiência do raciocínio do enunciador. De fato, enquanto essas palavras são pronunciadas, vemos um avião soltar uma bomba que cai lentamente antes de explodir e penetrar na terra.

O presente enunciado remete tanto ao enunciado precedente - como negligenciar o que compreendemos do mito que nos é enunciado, uma vez que essa mensagem ou a voz que a traz parece atender ao mais íntimo de nossos desejos, de nossos sonhos, sentimentos e preocupações?" - quanto à imagem que nos é apresentada, intimamente ligada, como mostraremos, à exposição seguinte.

Antes de apresentá-la, mas à luz do conhecimento de seu conteúdo, podemos adiantar a seguinte hipótese de uma leitura possível da frase citada no início do parágrafo: a voz desconhecida à qual se 
faz referência não remeteria, em última instância, à voz humana, mas designaria, antes disso, poeticamente, o próprio fenômeno que nos é apresentado, a bomba que cai.

Nesse contexto, o enunciado proposto poderia ser lido do seguinte modo: como não levar em conta, para compreender o sentido de um fenômeno que se produz diante de nós, o que já compreendemos intuitivamente - já que estamos na escuta da própria voz que emana do fenômeno que observamos - quando, pela primeira vez, sentimos, em nosso âmago, o impacto que o fenômeno observado cria em nós?

De fato, o que diz o próximo enunciado, que abre o movimento final da última grande parte do episódio, centrada em torno da idéia de uma lição das atualidades? .

"Eis a lição das atualidades, de Nascimento de uma Nação, de Espoir, de Roma, cidade aberta: o cinematógrafo nunca quis fazer um acontecimento, mas antes disso, uma visão. Porque a tela não é isso? - é feita com o mesmo tecido branco que faz a camisa do samaritano, o que as câmaras leves, inventadas por Arnold e Ritcher, reterão para não serem alcançadas pelo sonho e pelo pesadelo. Não é sobre a tela que o apresentaremos, mas sobre um sudário."

- Nos limites deste artigo, não tentaremos estabelecer um comentário exaustivo dessa passagem - por si só capaz de suscitar uma ampla discussão -, basta apenas pensarmos na referência feita a três filmes-chave da história do cinema. Portanto, deixaremos de lado, provisoriamente, essa referência para concentrarmo-nos no essencial do argumento proposto, relativo à lição das atualidades. .

Uma leitura possível do enunciado poderia ser assim adiantada: que lição as atualidades dão ao cinematógrafo? Ao contrário do que um certo tipo de cinema espetáculo propõe - do qual o trabalho de Leni Riefenstahl foi, à sua maneira, um êmulo -, a vocação original do cinematógrafo é a de testemunhar, de registrar e recolher os traços (o sudário) a fim de tornar possível uma visão, uma apreensão do acontecimento, e não a de construir ou de erigir um espetáculo.

Em seguida, uma referência alusiva e elíptica é feita às personagens e situações que não discernimos claramente, uma vez que essas referências estão, além disso, associadas a um novo enigma: "E se a morte de Puig e de Negus, a morte do Capitão de Boieldieu, 
a morte do coelhinho, foram inaudíveis, é que a vida nunca devolveu aos filmes o que ela lhes roubara". Entretanto, notemos que se faz referência aqui a dois filmes premonitórios de Jean Renoir: La Grande Illusion e La Régle du Jeu - filmes incompreendidos na ocasião de seu lançamento - e que a afirmação paradoxal, relativa à relação entre a vida e os filmes, visa suscitar no espectador, segundo nos parece, uma interrogação sobre o que vida roubou dos filmes.

O enunciado que segue: "e que o esquecimento do extermínio faz parte do extermínio", encontra-se, como veremos, ligado ao precedente pela conjunção $e$, conjunção que constitui por si só um novo enigma. Salientemos, sem tentar resolver esse enigma, que este último enunciado apresentado poderia ser compreendido desta maneira: o extermínio físico programado dos indivíduos encontra seu acabamento no esquecimento da existência efetiva, no passado, da materialidade desse fato, e do sofrimento moral, espiritual e corporal dos seres humanos exterminados.

Um pouco adiante, o tema da relação das massas ao imaginário produzido pela indústria do cinema, provisoriamente suspenso, encontra-se retomado, através de um enunciado de ordem mitológica: "Há quase 50 anos que, no escuro, a população das salas obscuras queima o imaginário para aquecer o real. Agora este aqui se insurge e quer lágrimas verdadeiras e sangue real".

Notemos que este enunciado parte da constatação de um fato histórico inegável: pela força de seus meios de expressão, o cinema, durante meio-século, transportou os espectadores para um alhures ficcional e sedutor que modificou sua visão e sua percepção do mundo.

Através desse enunciado mitológico, que afirma o desejo dramático do real de ver as tragédias da ficção se encarnarem na História, pode-se tentar, talvez, descobrir uma idéia central que, segundo nos parece, deve ser guardada: a da necessidade de o historiador considerar os elos recursivos existentes entre o domínio da ficção e o do real na história do cinema ${ }^{17}$.

17. O princípio do elo recursivo é, para Edgar Morin, um dos grandes princípios do pensamento complexo. O recurso a esse princípio permitiria, segundo ele, compreender melhor as situações em que os efeitos podem se transformar em causa e vice-versa (Morin, 1997 e 1999). 
No enunciado seguinte, o tema da vingança prossegue, desta vez associado a um outro tema, a ser retomado no antepenúltimo episódio da série, isto é, o da responsabilidade do cineasta diante dos efeitos que sua obra pode produzir nos espectadores: "Mas de Viena a Madri, de Siodmak a Capra, de Paris a Los Angeles e Moscou, de Renoir a Malraux e Djovenko, os grande diretores foram incapazes de controlar a vingança mil vezes encenada por eles".

"Histoire(s) du Cinéma, histórias sem palavras, histórias da noite", retoma o enunciador, antes de efetuar um novo balanço, poético, do papel histórico representado pelo pobre cinema de atualidades. Enquanto ele diz esse texto, dois planos se alternam na tela: um plano simples e sóbrio, exterior diurno, extraído de um filme de atualidades, que nos mostra um jovem sendo amarrado a um poste por um soldado, antes de ser fuzilado; e um plano eminentemente lírico, em que Gene Kelly dança em círculos com sua parceira, durante a noite, sobre um cais às margens do Sena.

O enunciador afirma: "É o pobre cinema das atualidades que deve lavar todas as suspeitas de sangue e de lágrimas, como deve-se limpar o calçamento quando já é demasiado tarde, e o exército já disparou sobre a massa", enquanto aparece esta frase sobre o fundo negro da tela: "Escrevo teu nome", e vemos, em plano de conjunto, um outro homem, de costas para o muro, com os olhos vendados, cair crivado de balas.

O sangue e as lágrimas devem ser lavados de toda suspeita de ficção, já que o papel do pobre cinema de atualidades encontra-se justamente aqui: registrar os traços do acontecimento, despojados de todo artifício representativo, para que ele possa se inscrever em nossa memória - para que o sangue e as lágrimas possam ser nomeadas , ainda que já seja muito tarde, e, por ser re-presentado, já fará parte do passado.

Se de fato é assim, destaca ainda o enunciador, certamente não é porque nas atualidades da guerra não haveria nenhum cinema, ou em outros termos, estabelecimento de um ponto de vista sobre a cena registrada:

"O que há de cinema nas atualidades da guerra não diz nada, não julga, nunca faz closes: o sofrimento não é uma star. Nem a 
igreja incendiada, nem a paisagem devastada. É a vez dos espíritos de Flaherty e de Epstein, e é Daumier e Rembrandt e seu terrível preto e branco. Poucas panorâmicas, uma plongée talvez, mas é porque uma mãe chora pelo filho assassinado."

Além disso, ou melhor, aquém tanto das referências a esses grandes nomes da pintura e do cinema, quanto das novas dimensões introduzidas pelo interrelacionamento do texto e das imagens, que lição nos é proposta com esse enunciado?

Pareceria possível, com o risco de empobrecer seu sentido, de dizer o seguinte: "o registro dos traços é uma operação sempre seletiva, não somente porque se efetua através de um instrumento criado pelo homem, que possui suas particularidades e seus limites, mas também porque ainda há, da parte do cinegrafista, a escolha de um ponto de vista, de certos ângulos e enquadramentos (o que há de cinema nas atualidades de guerra).

O dever do cinegrafista é assim o de ter uma consciência clara dos possíveis efeitos a serem engendrados pela seleção que ele pretende operar, adotando uma atitude de reserva que não acentue artificialmente os elementos dramáticos que a cena real registrada já possui - "nunca o close: o sofrimento não é uma star".

No fim do enunciado, pouco após o momento em que o enunciador diz "Poucas panorâmicas, uma plongée talvez, mas é porque uma mãe chora pelo filho assassinado", um plano médio, em leve plongée - extraído de um filme de atualidade -, nos mostra o corpo morto de uma mulher idosa, estirado no chão e ligeiramente coberto por um lençol branco; depois, um segundo plano, um pouco mais próximo, de origem indistinta, nos mostra uma mulher apertando em seus braços um bebê cujo corpo parece praticamente invisível, já que está envolto por vários tecidos; em seguida, um terceiro plano, extraído do filme La passagère, nos mostra uma orquestra de deportados, interpretando, ao ar livre, uma música de aparência clássica.

E é então que, progressivamente, esta última imagem se funde com um quadro de Goya surgindo lentamente, com o rosto sobressaltado de um rapaz e seus grandes bigodes, até a imagem permanecer sozinha, por um breve instante, sobre a tela. 
Aproveitando essa fusão, que se segue ao enunciado precedente, escutamos a voz em off do enunciador concluir seu raciocínio "e é porque desta vez, e somente desta vez, a única arte que verdadeiramente tenha sido popular reencontra a pintura, isto é, a arte, isto é, o que renasce do que foi queimado."

Através dessa ligação inesperada, completa-se o estabelecimento da relação entre o pobre cinema de atualidade e a pintura, introduzida por um enunciado anterior. A idéia sugerida, segundo nos parece, é a de que cinema de atualidade e pintura podem se encontrar, como instrumentos de recolhimento e meio de expressão dos traços do passado.

No fim desse enunciado, o rosto desenhado por Goya desaparece progressivamente sob uma reprodução do quadro Impression, soleil levant, de Monet, e depois aparece uma antiga gravura de uma virgem com um bebê adormecido em seus braços.

O enunciado seguinte liga a temática anterior à temática do esquecimento e da lembrança, girando em torno da oposição entre o que "se esqueceu" e o que "se lembrou", oposição binária que será retomada posteriormente, mais particularmente no episódio $4 \mathrm{~A}$, quando o enunciador evocar os filmes de Alfred Hitchcock.

$\mathrm{O}$ enunciador prossegue: "Esquecemo-nos dessa pequena cidade, e seus muros brancos, cercados por oliveiras, mas nos lembramos de Picasso; isto é, de Guernica", maneira de dizer, talvez, que se esqueceu da dimensão pitoresca da cena em que o acontecimento se produziu, mas que foi possível conservar a memória de sua existência, porque Picasso soube recolher os traços e construir a partir deles uma expressão.

O enunciado subsequiente retoma o mesmo tipo de oposição entre memória e esquecimento, para enfatizar, mais uma vez, a potência da memória que parece inscrever-se em certas obras da pintura: "Valentin Feldman, o jovem filósofo fuzilado em 43, foi esquecido Mas quem não se lembra de pelo menos um prisioneiro, isto é, de Goya." A referência ao esquecimento de Valentin Feldman e a evocação simultânea das circunstâncias de sua morte visam, segundo nos parece, contribuir para lembrá-lo. Notemos que assim que esse texto é dito, aparecem na tela imagens de jovens desconhecidos, enforcados, seguida por vários desenhos de Goya. 
A exploração do tema das atualidades prossegue ainda um instante, antes do balanço poético final, e permite-nos compreender melhor o sentido de um enigma apresentado logo no início do episódio: "a felicidade não é alegre".

De fato, o que nos diz neste momento o enunciador, junto a essas imagens de um amontoado de cadáveres de deportados, seguido de um plano aproximado de um deportado moribundo, arrastado pelo chão, puxado pelo colarinho de sua veste, e depois de uma imagem da jovem Elizabeth Taylor sentada com seu maiô, o rosto de Montgomery Clift deitado em sua perna, enquanto ela passa suavemente a mão em seus cabelos? "E se Georges Stevens tivesse sido o primeiro a utilizar o primeiro filme de dezesseis, em cores, em Auschwitz e em Ravensbruck, sem dúvida, jamais a felicidade de Elizabeth Taylor teria encontrado seu lugar ao sol." A idéia de um vínculo entre o reconhecimento da dor e a possibilidade de apreciação da felicidade é, indubitavelmente, uma das idéias fortes da série.

É então, ao que parece, que se estabelece o movimento final do episódio, com a última retomada, sintética, da enunciação dos anos da guerra, e a aparição de uma das últimas cenas de Alemanha, Ano Zero, de Roberto Rosselini, em que se vê um garoto hesitar por um instante, antes de se lançar do alto de um imóvel. Em seguida, o banho de Elizabeth Taylor, com o fotograma de Um lugar ao sol incrustado, através de um efeito de íris, no centro de uma imagem religiosa, na qual se vê o corpo de uma figura em posição de levitação, situado sobre a borda superior do quadro, os braços jogados adiante como se desejasse, de algum modo, preparar sua aterrissagem, ao mesmo tempo em que observa fixamente diante de si uma mão que surge na parte inferior do quadro, e que parece, por sua posição, fazer-lhe um apelo.

$\mathrm{O}$ enunciado que encerra a referência aos anos de guerra e que, simultaneamente, introduz uma nova dimensão poética no movimento final do episódio é o seguinte: "trinta e nove, quarenta e quatro, martírio e ressurreição do documentário. Ó maravilha, poder olhar o que não se vê, ó milagre de nossos olhos cegos".

Uma leitura possível da ligação estabelecida pelo enunciado poderia ser: uma vez que estivemos ausentes da cena do 
acontecimento, a atualidade nos dá, doce milagre, a possibilidade de reconhecer os traços que permaneceram.

Certamente, a incorporação das imagens que tentamos descrever dá toda uma outra repercussão ao conteúdo do texto, tornando mais complexo, como é habitual na série, o movimento da compreensão de seu sentido no contexto audiovisual em que se encontra inserido e suscitando, no espectador, uma inquietação interrogativa sobre o significado das associações estabelecidas inquietude que o conteúdo dos planos inseridos parece multiplicar.

$O$ enunciado seguinte nos leva a uma outra dimensão da história do cinema, a da geopolítica da indústria cinematográfica, o tema sendo reintroduzido com um tom aparentemente negligente: "além disso, o cinema é uma indústria e, se a Primeira Guerra Mundial permitira que o cinema americano arruinasse o cinema francês, o nascimento da televisão e a Segunda Guerra lhe permitiram financiar, ou seja, arruinar todo o cinema europeu."

Não cabe aqui comentar o balanço histórico estabelecido, o que por si só exigiria toda uma análise minuciosa. Mais simplesmente, notemos apenas que, a introdução de um novo dado, representado pelo nascimento da televisão - nascimento intimamente ligado à história da Segunda Guerra Mundial -, insere também a idéia de que sua incorporação à cena acarretará a ruína do cinema na Europa território central da história do cinema contada pelo enunciador.

Em seguida a esse enunciado, retornamos ao tema da cegueira, enquanto aparece um plano dos Nibelungen, de Fritz Lang, mostrando o herói atravessado por uma lança; o corpo curvado em direção ao chão. Esse movimento de propulsão do corpo para frente - ligado à morte - sendo retomado, de certa maneira, no plano seguinte, que nos mostra o garoto de Alemanha, Ano Zero hesitando um último instante, e colocando suas mãos fechadas sobre os olhos antes de lançar-se no vazio e morrer. $O$ texto do enunciado é o seguinte: “Tens duas mãos?, pergunta o cego. Mas não vai ser olhando que eu vou ter certeza. Sim. Por que confiar em meus olhos, se estou assim desconfiado? Sim, sim. Por que não serão meus olhos que vou encontrar ao olhar, se já vejo minhas duas mãos?" 
Observemos que a oposição final entre os olhos e as mãos pode ser considerada como sendo uma oposição entre olhar (olhos) e apreender (mãos). Note-se, além disso, que a tragédia representada pelo suicídio da criança de Alemanha, Ano Zero parece multiplicarse com as relações entre imagem e texto, já que a criança não confia mais em seus olhos e utiliza suas duas mãos como não um substituto provisório de um olhar cego, mas para poder perder-se definitivamente na noịte.

Antes do aparecimento, ao lado de um rosto de uma outra criança de olhar intenso, da inscrição a seguir, um antepenúltimo plano nos mostra, encravado na sombra por uma íris que o cerca, o célebre ator cômico do cinema mudo francês, Max Linder, andando sobre uma praia, com a sentença "últimas palavras de Max Linder" vindo entạo inscrever-se na tela, enquanto a voz em off diz: "socorro".

\section{Episódio 1B: Une seule histoire}

No decorrer da parte introdutória desse episódio, a idéia de uma história só, presente no título, encontra-se ligada ao tema do silêncio - brevemente evocado em meio ao episódio precedente - e depois à idéia de uma escuta solitária de um sussurro, trazendo a idéia poética de uma solidão da história, ela própria geradora de uma sucessão de enunciados, que mantêm diversas relações com o título do episódio.

Inicialmente, escutamos a voz em off dizer: "Esteja certo de ter esgotado tudo o que se comunica pela imobilidade e o silêncio"18. Em seguida, surge uma série de subtemas ligados uns aos outros em virtude de sua sucessão.

Um dos enigmas do episódio precedente é inicialmente repetido: "O que passou pelo cinema conservou sua marca e não pode mais entrar em outro lugar". Compreenderemos, no decorrer

18: Notemos que, para o enunciador, uma das principais singularidades do cinema é seu poder de evocação do indizível e do invisível. Porém, essa capacidade singular do cinema só será evocada no episódio $2 A$, associado a esse mesmo enunciado. 
deste episódio, que essa afirmação tem relação com a dificuldade, essencial para o enunciador, da introdução da arte do cinema no dispositivo da televisão.

Depois, o enunciador verbaliza, ironicamente, uma interrogação sobre a relação entre sua história pessoal, o universo audiovisual da série e o fragmento em que seu discurso se encontra inserido, agindo na relação entre zonas de sombra e de obscuridade. "Mas para mim, inicialmente, a minha, minha história. E o que tenho a ver com tudo isso, toda essa claridade, toda essa obscuridade"19.

Sem responder à questão lançada por ele mesmo, ele prossegue prontamente o seu discurso, assumindo um outro tom: "Às vezes, durante a noite, alguém sussurra em meu quarto, desligo a televisão, mas o sussurro continua". Notemos que a referência à televisão sugere a idéia de um dispositivo tagarela, havendo, simultaneamente, a constatação da existência do sussurro e a dúvida sobre a sua natureza. Além disso, uma série de enunciados desse episódio e de diversos episódios subsequientes joga com essa idéia de um murmúrio enigmático.

A dúvida sobre a natureza do sussurro traz a idéia da possibilidade da existência de um vento vindo do fundo das eras - "será o vento ou meus ancestrais" - e, imediatamente após, a da "história da solidão"; a escolha das imagens associadas parece tornar mais tangivel a realidade dos enunciados. Note-se que o enunciador tenta compreender o sussurro seja como índice de uma energia exterior invisível, mas efetivamente presente (o vento) e da presença em sua lembrança de seres desaparecidos (meus ancestrais). Pode-se também considerar a idéia poética do vento como um tipo de rumor murmurado do ente.

Observa-se que o tema poético do sussurro será ligado, dentro deste episódio, ao da projeção e, de modo subliminar, à figura de Langlois, grande ancestral, que ao projetar na cinemateca da Avenue de Messine os filmes de um cinema até então invisível, "ofertou um passado metamorfoseado em presente" à geração da Nouvelle Vague - como enunciador o mostrará no episódio $3 \mathrm{~A}$.

19. Notemos que a questão levantada por essa relação será metodicamente abordada no próximo episódio. 
Após a referência à história da solidão, o tema do vento, tornado visual, associa-se à idéia - enunciada verbalmente - de uma solidão da história, estabelecendo assim uma passagem para o próximo segmento, em que se começa a explorar o tema central do episódio: o da singularidade da narrativa do cinema ${ }^{20}$.

É porque, segundo nos parece, o título da série-Histoire(s) du Cinéma - é então inserido sobre o fundo negro da tela.

Para explorar o tema da narrativa, o enunciador recorre ao relato de uma lenda poética, que é, de certa forma, um mito de origem: "O cinema projetava e os homens viram que o mundo estava lá. Um mundo ainda quase sem história. Mas um mundo que conta".

Assim - poder-se-ia pensar -, os homens descobriram, graças à capacidade nova e única da projeção própria ao cinema, e sobretudo através de seus relatos, um mundo que até então lhes era invisível. O homem redescobria o mundo, originário, ainda sem relatos e, simultaneamente, a capacidade que esse mundo possuía de contar relatos ${ }^{21}$.

A próxima questão evocada relaciona-se aos temas privilegiados sobre os quais esses relatos se edificaram. Entretanto, antes que a voz em off anuncie com ênfase o ponto de vista defendido, um outro enunciado, mítico, nos é apresentado: "A imagem virá no tempo da ressurreição / A imagem virá, ó tempo da ressurreição"22.

20. Observemos que, para Godard, a idéia da solidão da história também remete à idéia de um afastamento da História com relação aos homens. Dirigindo-se a um auditório alemão, por ocasião da atribuição do prêmio Adorno em Frankfurtsobre-Main, Godard declarou: "Minha idéia é a de que a história está sozinha, longe do homem.." (Apud. Bergala, 1988, p. 402).

21. "Para Pierre Janet, lembra Bachelard, não é a recepção quem cria a humanidade, mas a narração." (Apud. Candau, 1996, p. 32).

22. Godard salienta, em duas entrevistas, o sentido do uso dessa expressão: "Quando leio em Sāo.Paulo que a imagem virá no tempo da ressurreição [...] após trinta anos de montagem, começo a compreender: para mim, a montagem é a ressurreição da vida." "São Paulo disse: a imagem virá no tempo da ressurreição. Não se deve tomar a palavra ressurreiçāo no sentido de que o sujeito vai para o céu. Antes disso, trata-se da ressurreição de alguma coisa que passou" (Apud. Bergala, 1988, p. 246 e 430). O tema do vínculo entre imagem e ressurreição será retomado no episódio $4 A$. 
Esse enunciado se inscreve sobre a tela, entrecortado por fragmentos de cenas do filme Duelo ao sol, no qual vemos a personagem interpretada pela atriz Jennifer Jones retesar-se sob o impacto de um tiro disparado pela personagem interpretada por Gregory Peck; depois ela cai no chão, ao lado de seu fuzil; em seguida, ela se ergue e se arrasta pelo chão com a arma na mão, antes de alongar-se ao lado de Peck e, agitada e perplexa, acariciar-lhe o rosto.

Observemos que esses fragmentos de cenas, mostrando uma moça com um fuzil, vem jogar, num primeiro momento, com a memória do espectador, já que no episódio precedente, quando se evocava a história de Hollywood, havíamos visto o slogan "O filme é uma moça com uma arma" inscrever-se na tela. Convém, em segundo lugar, assinalar o sentido que o realizador dá ao enunciado mítico apresentado, uma vez que esse permanece em suspenso, ao que parece, para a maior parte dos espectadores. Para Godard, é o relato constituído pela montagem que dá vida às imagens, fazendo-as ressurgir do passado.

Antes que o fim do enunciado se inscreva sobre a tela, escutamos a voz em off dizer: "Mas para instalar a idéia e a sensação em vez da incerteza, as duas grandes estórias [da indústria do cinema] foram o sexo [a moça] e a morte [a arma]".

Interrompamos um instante a nossa apresentação do desenrolar do episódio 1B Para tentar compreender, pelo menos parcialmente, o sentido desse enunciado, já que essa compreensão é essencial à compreensão das idéias centrais da série.

Para isso, precisamos nos referir a um outro enunciado, presente no início do episódio 2B: "O instante fatal sempre virá nos distrair". Como esse segundo enunciado pode nos ajudar a compreender o primeiro? Nossa idéia é a seguinte: se o amor, terreno fértil da incerteza, se resume ao sexo, o que conta é o instante fatal do gozo, e é essa a sensação buscada antes de qualquer coisa; se, além disso, não se dá lugar à incerteza humana sobre a possibilidade da existência de uma passagem espiritual a uma outra dimensão após a morte física do corpo, o instante em que a morte se produz sempre é irrevogável, decisivo, e, por conseguinte, facilmente transformável num espetáculo dramático 
capaz de produzir um impacto violento em nossa sensibilidade um impacto sensacional ${ }^{23}$.

Após afirmar que as duas grandes histórias foram o sexo e a morte, o enunciador encadeia a sequiência lógica e peremptória de seu raciocínio, a fim de problematizar o lugar de pertença do cinema: "Em suma, histórias de beleza, a beleza, a maquiagem. No fundo, o cinema não faz parte da indústria da comunicação, nem da do espetáculo [lugares habitualmente reconhecidos como próprios do cinema], mas da indústria das máscaras, que, em si, não é senão uma pequena filial da indústria da mentira."

Note-se que a série de equivalências peremptórias estabelecidas sugere - uma vez que a indústria do cinema está assimilada à dos cosméticos -, que a indústria do cinema é uma indústria produtora de traços aparentes, sedutores e enganadores. Como veremos, há no fim do episódio uma sugestão poética da idéia de um outro cinema, capaz de ler, à maneira do poeta, os traços inaparentes dos deuses evadidos.

A seqüência do enunciado parece seguir a mesma lógica problematizante. Observemos aqui a introdução de um novo tema, o da herança recebida da fotografia, assim como a idéia de que a tentativa de ser mais verdadeiro do que a vida conduz à mentira: "Histórias do cinema, é por aí que se retorna ao espetáculo, não se pode explicar de outro modo, já que por ser herdeiro da fotografia, o cinema sempre quis ser mais verdadeiro do que a vida." Além disso, o vínculo do cinema com a morte encontra-se simultaneamente destacado através da inscrição, sobre extratos de filmes desfilando na tela, do enunciado: "Uma indústria da morte".

Imediatamente, o enunciador introduz uma idéia central, que o espectador parece predisposto a aceitar; já que, confuso em meio à abundância das proposições semânticas que lhe são ofertadas, ele já

23. Ora, a série nos diz que, após a morte, traços de nossa passagem, efêmera, permanecerão no mundo dos vivos, nem que seja apenas na lembrança dos vivos. A partir disso, o cinema é visto como um potente e único instrumento de conservação da lembrança, como um lugar privilegiado de sua inscrição, já que, após nossa morte, somente ele pode transmitir uma imagem viva, em movimento, de nós. 
não sabe, nesse instante do desenrolar da série, em que se apoiar: "Eu dizia: nem uma arte, nem uma técnica, um mistério."

A idéia subjacente à inserção deste último enunciado parece ser a de destacar que o cinema, além de sua dimensão artística e da instrumentalização de suas técnicas pela indústria - ser mais verdadeiro do que a vida, dar a vida como um espetáculo, para que ela pareça mais verdadeira do que realmente é, etc. - possui uma outra qualidade, ainda não desvelada, misteriosa, que se trata de descobrir.

A idéia de um mistério do cinema é imediatamente associada à da solidão, através do duplo enunciado "história da solidão, solidão da história". História da solidão parece sugerir a idéia de uma solidão da história do cinema. Já solidão da historia parece, antes disso, remeter à idéia da história contada, como veremos a seguir.

Em seguida, retornamos mais uma vez à noção do cinema como indústria da mentira: "Assassins et voleurs, o último filme de Guitry. Logo, a cada manhã, não haverá mais a necessidade de ir ao mercado onde são vendidas as mentiras. Logo, não ela não estará mais, todo alegre, ao lado dos vendedores. Registrei essa frase de Brecht, e pedi a Fritz Lang que a dissesse a Brigitte Bardot. Chamei esse filme de Le Mépris".

Escutamos a voz de Godard dizer esse enunciado e, após a apresentação de alguns extratos de filmes, vemos o rosto de Godard surgir na tela, deformado por uma série de superposições. Lemos então sobre a tela: "a história, não quem a conta".

Notemos que esse comentário é feito no momento em que o pronome pessoal eu é utilizado de modo reiterado pela voz em off de Godard, como um outro modo de dizer: "cuidado, mesmo quando falo de mim, de minha experiência, não me concedam demasiada importância, sou apenas o enunciador de uma história, o mais importante é a história em si, o relato de uma trajetória - resultado de toda uma vida". Notemos, por outro lado; que há, simultaneamente, uma auto-ironia: "estou thes dizendo que o importante não sou eu, mas é de mim que falo, logo eu também posso mentir".

Subseqüentemente, retornamos às origens do cinema "bem no início" -, no tempo original a partir do qual a história do cinema se desenvolveu, e de onde surgiram, em consequiência, todas as histórias do cinema. 
A evocação adota inicialmente um tom humorístico - "a história de dois irmãos, eles poderiam se chamar abajur, mas eles se chamavam Lumière [luz], e eles tinham quase a mesma bobine [bobina e ao mesmo tempo rosto]" -, antes de assumir uma dimensão mais propriamente lendária, a fim de que se possa estabelecer a origem mítica do mistérió aludido há pouco.

O enunciador então nos ensina: "Para se fazer cinema, há sempre duas bobinas, uma que se enche, outra que se esvazia. Como por acaso, chama-se a bobina da esquerda de escrava e a direita de mestra". O uso da palavra escravo vai permitir, dentro em breve, um jogo de palavras complementar, versando sobre a idéia de uma memória escrava.

Pouco depois, uma imagem nos mostra o close de um homem e uma mulher, olhando fixamente em frente, rostos colados num pequeno projetor; sobre o qual há superposta a imagem de uma bobina que gira a toda velocidade ${ }^{24}$. Um segundo close se segue, revelando desta feita o rosto de Greta Garbo duplicado por um espelho, com as palavras "Sem füturo" inscritas sobre sua pele, ao passo que, simultaneamente, o enunciado das origens começa a ser dito: "É porque, pela última vez, a noite reúne suas forças para vencer a luz. Mas é pelas costas que a luz vai atingir a noite”.

Notemos o jogo de duplo sentido da palavra luz e sua subseqüente oposição ao termo noite. Graças a essa oposição, surge a idéia do combate decisivo e trágico, vindo das eras mais remotas, entre as forças da noite e as forças da luz, combate que vai estar na origem do advento da projeção luminosa - como se sabe, ela vai do fundo em direção à frente, perfurando, literalmente, o escuro das salas de projeção. Observe-se também que a inserção simultânea de imagens religiosas, rigorosamente escolhidas, reforça com muita sutileza o conteúdo poético do segmento.

Posteriormente, num momento-chave do episódio 4B, reveremos uma dessas imagens, a reprodução de uma fotografia do rosto esculpido de uma virgem, com a face suavemente iluminada e

24. Notemos que a imagem desse casal ao projetor é uma das imagens que retomam com mais freqüência na séne. Ela será mais particularmente presente no épisódio $4 B$. 
investida de uma serenidade atenta, em meio à profundidade do escuro da noite.

A imagem subseqüente, de difícil decifração em virtude de seu jogo de sobreimpressões, nos revela, entre outros elementos, a silhueta de um cinegrafista em ação, com as palavras "O homem com a câmara" vindo inscrever-se na tela. Depois, uma outra imagem nos mostra uma janela entreaberta; sobre o vidro aparece, de modo bastante apagado, o rosto de Henri Langlois, enquanto o enunciador retoma o tema do sussurro do início do episódio, ligado aqui à idéia de um mistério original, insondável, que o homem teria desvendado antes mesmo de existir: "E inicialmente muito suave. Como se não se quisesse amedrontá-lo. O sussurro que o homem já desvendou. Há muito tempo. Ó, tanto tempo, muito antes de o homem existir."

Observe-se que a idéia de um sussurro bem suave remete, poeticamente, à idéia do cinema originalmente mudo, e que o enunciado passa a associar-se a um plano de um filme mudo de Dreyer, Les fiancées de Glomdal, que tem um papel capital na série, uma vez que está associado, particularmente no episódio $2 \mathrm{~A}$, ao mito de Orfeu e à figura de Caronte, barqueiro que transportava a alma dos mortos para levá-los ao reino de Hades. O plano aqui inserido nos mostra um barqueiro - de pé na proa de uma barca, as mãos ocupadas com um longo bastão, a cabeça virada - e ao fundo da barca uma mulher deitada, podendo estar adormecida, desmaiada ou morta.

A voz em off destaca a repetição de um sussurro - "o sussurro recomeça" - depois o discurso muda mais uma vez de tom: "É que um projetor de filmes é obrigado a lembrar-se da câmera e que o cinema só é uma indústria da evasão, porque é antes de mais nada o único lugar em que a memória é escrava."

Mais uma vez, notemos o apelo aos aforismos ${ }^{25}$, às afirmações paradoxais e a um princípio dialógico que une enunciados

25. Em uma entrevista, Godard fala de "sua inclinaçāo ao uso de aforismos, sínteses, provérbios", e salienta que esse gosto advenha "talvez das fórmulas científicas. $\mathrm{O}$ aforismo resume alguma coisa ao mesmo tempo em que permite outros desenvolvimentos. Como um laço: ele poderia ser feito em outro sentido, o que não impede que quando ele é feito, o sapato fique bem assim. Não é o .pensamento, mas um traço do pensamento" (Bergala, 1988, p. 437). 
aparentemente contraditórios, para poder destacar o vínculo existente. entre a capacidade de projeção para um alhures, proporcionada pelo dispositivo cinematográfico, o efeito de evasão criado por este dispositivo, e a capacidade de conservar materialmente traços de cenas passadas. Sucintamente, observemos um dos ensinamentos da lógica paradoxal desse enunciado: é justamente por conservar a memória, fazendo dela o seu único lugar, que o cinema favorece uma fuga do sujeito para fora do presente.

Subsequientemente, a voz em off retoma o tema da herança da fotografia: "Sim, herdeiro da fotografia. Mas ao herdar essa história, o cinema não herdava somente direitos de reproduzir uma parte do real, mas sobretudo iseus'deveres:", Notemos que dois enunciados - inscritos sobre a tela completam o sentido de dever: "A sombra de uma dúvida; a lei do silêncio", e que há aqui a afirmação implícita da idéia de um vínculo obrigatório do cinema ao real-ou, pelo menos, a uma de suas partes - através da herança da fotografia... , , .

$\mathrm{O}$ tema da herança prossegue "e alcança a literatura e a pintura r a natureża dessa herança estando enigmaticamente indicada em torno da idéia poética do álbum de família - que poderia ser. compreendido como representando uma realidade próxima,'cotidiana; pertencente à experiência temporal própria ao artista! "E se"ele herdou de Zola, por exemplo, não foi de A'taberna, nem da Besta humana," mas, primeiro, de um álbum de família; isto é; de Proust e de Manet"..

Retorna entã́o, com toda força, o tema da ficção contra o real; còmo vimos; esse tema representou um papel central no episódió precedente: "Para ir do início ao fim deste livro imenso, com o qual os'homens violaram desesperadamente a natureza para nela semear a potência de sua ficção; para ir de Giotto a Matisse e de Madame de la Fayette a Faulkner, será preciso cinco vezes menos tempo do que fora preciso para a que primeira locomotiva se tornasse o trem bala".

Observemos que junto a essa alusão peremptória, metafórica e mítica do percurso desse livro imenso vem a introdução das idéias que parecem essenciais e fecundas: com o advento da indústria da evasão constituída pelo cinema, acelera-se a passagem à ficção e ao estabelecimento de relatos mentirosos - a violação da natureza -; com o cinema, evoluções que foram seculares na história das outras 
artes passam a ocorrer muito mais velozmente. A alusão à rapidez da evolução das técnicas parece, em si, servir para destacar que o estabelecimento de relatos mentirosos ocorre bem mais rapidamente do que a evolução, já acelerada, das técnicas.

Com a determinação desse trágico percurso histórico de um certo cinema, o enunciador retorna, implicitamente, isto é, visualmente - através de da escolha de extratos de filmes - Jeanne au bûcher, Procès de Jeanne d'Arc, Ordet, Um cão andaluz, Marnie, La terre tremble, Paisa -, a um outro cinema e, explicitamente, isto é, oralmente, ao tema central do episódio, o relato do cinema.

Ele se preocupa em distinguir este último relato do relato histórico: "O cinema, assim como o cristianismo, não se funda sobre uma verdade histórica. Ele nos dá um relato, uma história, e então nos diz: creia".

Uma das leituras possíveis do enunciado apresentado é que o cinema, do mesmo modo que o cristianismo, nos oferece relatos fundadores, pedindo-nos que creiamos neles, em função de uma verdade que não saberíamos identificar de imediato.

Notemos que Godard, ao caracterizar a operação realizada pelo cinema, evoca também sua própria démarche, já que, como sabemos, a longa narrativa constituída pela série é o resultado de toda a sua vida de cineasta, de crítico e de homem: "Não conceda a esse relato, a essa história, a fé que convém à história, mas creia, o que quer que aconteça, só poderá ser o resultado de toda uma vida. Eis aqui um relato, não o trate como se fosse um dos outros relatos históricos." Vê-se então sobre a tela imagens extraídas de Ordet, de Dreyer. "Dê-lhe um lugar diferente".

Nesse momento, aparece na tela uma série de fotogramas de $O$ cão andaluz, de Buñuel, mostrando-nos dois dedos da mão esquerda de um homem separando as pálpebras de uma mulher, para poder, com a faca presa na mão direita, cortar seu olho. Quando o enunciador diz "Dê-lhe um lugar diferente em sua vida". Antes da inserção do close da faca cortando o olho, surge uma pintura antiga, de atmosfera doce, em que se pode perceber duas crianças.

Em virtude da associação das palavras e das imagens, sugerese subliminarmente que uma das razões que faz com que o espectador tenha de conceder um outro lugar para o relato do cinema em sua 
vida, está no fato de que a construção desse relato tem como base um procedimento técnico e semântico próprio ao cinema: a montagem.

Pouco depois, reaparecem dois enunciados apresentados anteriormente. O primeiro encontra-se escrito sobre a tela: "A imagem virá no tempo da ressurreição". O segundo é introduzido oralmente por essas palavras: "Isso para dizer que o cinema...", seguido pela inscrição "O cinema, diga-o de novo", entremeado por fotogramas de extratos de La terra trembla e de Paisa. Depois, retorna o enunciado, ligeiramente modificado e truncado: "Isso para dizer que o cinema nunca foi uma arte e ainda menos uma técnica".

Essa afirmação é justificada pelo exemplo da evolução da câmera no decorrer da história do cinema, com o enunciador constatando a ausência de mudanças fundamentais e defendendo a idéia de que os dispositivos anteriores podem ser melhores do que os seus sucessores. "A Panavisium platinum é menos aperfeiçoada do que a Debrie 7 '.

Em seguida, após ter evocado de maneira elíptica os argumentos contrários, tendo-os refutado de maneira também elíptica, o enunciador retorna à idéia principal e evoca com humor, mais uma vez, os dois irmãos, evocação graças à qual, como acabamos de ver, reintroduz-se o tema da televisão: "Não é uma técnica nem mesmo uma arte, uma arte sem futuro, desde o princípio os dois irmãos gentilmente nos advertiam".

Antes de prosseguirmos a transcrição do enunciado, observemos a referência implícita à opinião declarada dos irmãos Lumière - segundo a qual o cinema era uma arte sem futuro - que permitira ao enunciador estabelecer uma equilavência entre arte sem futuro = arte do presente, razão pela qual introduz-se, após a alusão aos dois irmãos, o enunciado “em primeiro lugar”, ao qual se seguirá, mais adiante, "aliás" - anuncio uma digressão -, e, pouco depois, "e em seguida".

Retomemos o fio do enunciado: "Inicialmente - e isso não faz nem cem anos - vê-se que eles tinham razão e que se a televisão realizou o sonho de Léon Gaumont, levar o espetáculo do mundo inteiro até o mais miserável quarto de dormir, foi em função da redução do céu gigante dos pastores". Vemos então sobre a tela o ator Charlton 
Heston abrindo os braços durante a passagem do Mar Vermelho no filme Os dez mandamentos, enquanto as palavras Dark Victory vêm se inscrever sobre os fotogramas do filme $A$ la hauteur $d u$ Petit Poucet [à altura do pequeno polegar].

Note-se que o enunciador, inicialmente, dá crédito às proposições dos dois industriais de Lyon, os Lumière, para enfatizar o amargo destino que a televisão reservou ao cinema, realizando a antiga idéia de colocar o mundo ao alcance dos espectadores.

Graças a um novo jogo de palavras - petit poucet $\mathrm{X}$ enfantin [pequeno polegar $\mathrm{X}$ infantil], o enunciador introduz então uma breve digressão, evocando o barão Enfantin, um dos dois sacerdotes supremos do colégio dos santos Simonienses, que estabeleceu, em meio ao século XIX, uma leitura cada vez mais redutora da doutrina de São Simão, ignorando o movimento socialista então em desenvolvimento, e modificando seu interesse progressivamente para a construção das estradas de ferro, razão pela qual o enunciador conclui sua alusão com as palavras "a caminho, o sonho se havia mecanizado". No plano seguinte, o fim do enunciado introduz um novo jogo de palavras, com a inscrição sobre a tela das palavras: "Sangue por vir".

Observe-se que há a sugestão, nesse segmento, da idéia de que a televisão, além de reduzir o céu gigante dos pastores à altura do pequeno polegar, mecaniza nossos sonhos. A idéia do sangue por vir associada ao fim do enunciado permanece em suspenso.

$O$ enunciador retoma então o fio de seu raciocínio, ao defender a idéia de que os irmãos Lumière foram mal compreendidos; graças a essa mudança de direção, a plenitude do mistério do cinema começa a ser poeticamente desvelada: "E em seguida eles foram incompreendidos, eles diziam sem futuro, isto é, uma arte do presente, uma arte que dá, e recebe antes de dar, digamos, a infância da arte".

Note-se o jogo poético das equivalências e sua progressão: a idéia da ausência de futuro conduz à do presente, a do presente à do dom, e esta última permite a introdução da idéia de uma nova arte que recebe (registra) antes de dar (projetar); esta última, por sua vez, traz a idéia da criança - que, de fato, recebe a vida como um dom, antes de poder, mais tarde, também dar a vida. A noção de 
infância conduz à da infância da arte, que nos leva à da primeira era do cinema, era do cinema mudo - como se sabe, infans, em latim; designa aquele que não fala.

À idéia do cinema como infância da arte se segue a de que sua emergência é contemporânea à abertura das portas da noite.

Após o último enunciado, surge na tela uma imagem de Charcot na Salpêtrière, segurando em seus braços uma histérica adormecida; depois vem uma imagem de Griffith filmando sobre uma calota de gelo, imagem sobre a qual pode-se ler as palavras As portas da noite; depois, um fotograma de um de seus filmes - Órfãs da tempestadeem que se vê Lilian Gish deitada sobre a calota de gelo.

A voz em off diz: "E é a noite do século XIX, é o início dos transportes públicos e é a aurora do século $\mathrm{XX}$, são os debates sobre o tratamento dá histeria, é o velho Charcot que abre ao jovem Freud as portas do sonho. A ele de encontrar a chave dos sonhos. Mas onde está a diferença entre Lilian Gish deitada em sua calota de gelo [repete-se o plano com Lilian Gish] e:Augustine na Salpêtrière [surge uma fotografia de Augustine deitada numa cama na Salpêtrière]."

O próximo enunciado nos encaminha para o fịm do episódio, onde se estabelece um tipo de balanço poético final da primeira parte, composta pelos dois episódios 1A e 1B.

Surge um outro tom, desta feita elegíaco, intimamente ligado, segundo nos parece, ao tema da televisão, cuja imagem poética na série tem múltiplas relações com a visão de uma estreiteza do mundo. Se o advento do cinema é poeticamente ligado, no segmento precedente, à abertura das portas da noite, a televisão, no conjunto da série, parece ser, junto à fome e à miséria, um dos sintomas maiores da existência de um tempo do desalento.

O enunciado - que apresentaremos de uma só vez por comodidade de exposição - é o seguinte: "Mas o pior ainda se enuncia quando deus falta. Não somente deus e os deuses fugiram, mas o esplendor da divindade apagou-se na história do mundo. $\mathrm{O}$ tempo da noite do mundo é o tempo do desalento, pois este mundo torna-se a cada dia mais estreito. Ele chegou a tornar-se tão estreito que não é nem mesmo capaz de abrigar a falta de deus como uma falta". 
Imediatamente depois, é introduzida a idéia de uma perversão do estado da infância - que a arte do cinema representava em seu início. Essa idéia liga-se às duas guerras mundiais: "Em seguida, bastará uma ou duas guerras mundiais para perverter esse estado infantil e para que a televisão se transforme nesse adulto imbecil e triste, que se recusa a ver o buraco de onde nasceu e se isola então em criancices" 26 .

Lembremos que foi na Alemanha, sob o regime de Hitler, durante as Olimpíadas de 1936, que houve a primeira transmissão televisiva. Sem dúvida, foi por essa razão que se inseriu uma imagem do ditador pouco depois do momento em que a voz em off diz: "E para que a televisão transforme...".

. Em seguida a essas referências históricas elípticas, enunciase, de modo fragmentado, o último grande mito de origem desse episódio, ligado de forma subliminar, segundo nos parece, ao tema do holocausto, vinculado de forma explícita ao tema do luto. Além disso, esses temas representam um papel fundamental na série como um todo.

Por comodidade de exposição, apresentaremos o texto de uma só vez: "Porque eis o que aconteceu: na madrugada de século $\mathrm{XX}$, as técnicas decidiram reproduzir a vida. Inventou-se, assim, a fotografia. Mas como a moral ainda era demasiadamente forte e que se preparava para retirar da vida até mesmo a sua identidade, vestiuse o luto desse assassinato e é com as cores do luto, com o negro e com o branco, que o cinema passou a existir".

Observe-se que quando o enunciador diz as últimas palavras, vemos sobre a tela um dos planos de Ordet de Dreyer, filme em que o tema da ressurreição cumpre um papel fundamental.

Salientemos, brevemente, dois aspectos da lenda que nos está sendo contada: o papel atribuído às técnicas que se teriam outorgado a decisão de reproduzir a vida-em seguida a eșsa decisão, a foto teria sido inventada; o apelo à idéia paradoxal de vestir o luto de uma morte que ainda não ocorreu.

26. Lembre-se de que o enunciador havia, no fim do episódio precedente, ligado o nascimento da televisão à história da Segunda Guerra Mundial. 
Note-se, em seguida e também brevemente, que o segmento "que se preparava para retirar da vida até mesmo sua identidade", suscetível de uma diversidade de leituras, sugere a idéia de que a representação-de base fotográfica-seria um roubo ${ }^{27}$, e que a associação desse segmento com o seguinte - vestimos o luto desse assassinato sugere a leitura de uma programação de assassinato da vida, noção suscetível de ser ligada, por sua vez, à temática do holocausto.

Parece-nos importante destacar um último ponto: quando é dito "é com as cores do luto, com o negro e com o branco", vemos surgir na tela, incrustados sobre fotogramas de filmes, as palavras "que a vida devolva ao cinema o que ela roubou dele". Uma das múltiplas idéias sugerida pela associação dos enunciados é, certamente, que a vida devolva ao cinema as outras cores que the haviam sido retiradas.

O enunciado subseqüente retoma a temática dos deuses evadidos e constitui, como já destacamos, um balanço poético final da parte composta pelos dois primeiros episódios.

$O$ balanço se estabelece em torno da idéia da necessidade que o poeta tem, em tempos de desalento, de estar atento ao traço inaparente dos deuses em fuga, para poder traçar para os mortais, seus irmãos, o caminho do reviramento.

Parece possível, à luz do percurso composto pelas duas partes, sugerir a hipótese de que, sob a figura do poeta podemos encontrar o traço da figura do cineasta. É, sem dúvida, por essa razão que, no início do enunciado que iremos transcrever, o enunciador colocou uma imagem com o rosto de Carlitos - sobre qual se inscreve as palavras "Oh! that cello" - e, que no fim do enunciado e do episódio, quando o enunciador diz "no tempo da noite do mundo, o poeta diz o sagrado", vemos surgir uma imagem de Vertigo, filme de Hitchcock, que, segundo o enunciador, é "o único que, juntamente com Dreyer. soube filmar um milagre" - frase extraída do episódio 4A.

27. É o próprio autor quem propõe essa leitura. Durante uma conferência em 1989, na FEMIS, pouco antes da estréia desse primeiro episódio, Godard observava: "Eu diria do meu modo que, a partir do momento em que se roubava da vida a sua própria imagem, em que a representação era um roubo, era mesmo necessário vestir o luto" (p. 245). 
O último texto, que transcreveremos de uma única vez, é o seguinte: "Os poetas são aqueles dentre os mortais que, cantando gravemente, ressentem o traço dos deuses evadidos, permanecem nessa trilha e traçam para os mortais, seus irmãos, o caminho do reviramento. Mas quem dentre os mortais é capaz de identificar um traço desse tipo? Esses traços se caracterizam com freqüência justamente por serem inaparentes, sendo sempre o legado de uma atribuição quase impressentida. Ser poeta em tempos de desalento é, então, cantando, estar atento aos traços dos deuses evadidos. Eis porque, no tempo da noite do mundo, o poeta diz o sagrado."

Limitemo-nos a salientar alguns pontos de forma sucinta, propondo uma primeira leitura: o dom que, por graça, o poeta, simples mortal, recebeu é um dom de recolhimento e de expressão; em virtude da graça que o habita, ele sente a ausência de Deus como uma perda e canta gravemente, exerce seu dom de expressão para poder, através dele, colocar-se em posição de recolher, intuitivamente, o traço inaparente dos deuses evadidos.

Sua missão não se resume a identificar a existência de traços, nem mesmo a descobrir do que eles são índices. Ele precisa, mais do que isso, restabelecer o percurso da perda e retraçar esse percurso para outrem, para poder, a partir desse momento, tornar possível a iniciativa coletiva do reviramento.

Imemorial, já que contemporânea da morte dos deuses, a atribuição, que permitirá identificar o caminho da mudança, é sagrada.

Eis talvez porque, no tempo da noite do mundo, o poeta diz o sagrado.

\section{Bibliografia}

ALENCASTRO, L.F. de. 2000. 'O holocausto e a "incultura do mal"'. NO, 3 de out.

AUMONT, J. 1999. Amnésies. Fictions du cinéma d'après JeanLuc Godard. Paris: P.O.L.

AQUIEN, M, 1996. "Introduction à la poétique". In: AQUIEN, M. e MOLINIÉ, G. Dictionnaire de Réthorique et de Poétique. Paris: Éditions Le Livre de Poche. 
BENJAMIN, W. 1991. Charles Baudelaire, um lírico no auge do capitalismo. São Paulo: Editora Brasiliense.

BERGALA, A (org.). 1988. Jean-Luc Godard par Jean-Luc Godard. Paris: Cahiers du Cinéma.

-. 1999. "L'ange de 1'histoire". In: BERGALA, A. Nul mieux que Godard. Paris: Cahiers du Cinéma., p. 221-249.

CANDAU, J. 1996. Anthropologie de la mémoire. Paris: PUF.

CERTEAU, M de. 1987. "Lacan: une éthique de la parole". In: CERTEAU, M. de. Histoire et psychanalyse entre science et fiction. Paris: Gallimard, p. 168-196.

DOUCHET, J: 1998. "Images arrachées au journal du siécle". Art Press, Hors Série: Le siècle de Jean-Luc Godard / Guide pour "Histoire (s) du Cinéma". p. 27-31, nov.

FOREST, P. 1998. "La rose dans la poussière de l'acier". Art Press, Hors Série: Le siècle de Jean-Luc Godard / Guide pour "Histoire (s) du Cinéma". p.13-26, nov.

GERVAISEAU, H. 2000. O abrigo do tempo. Abordagens cinematográficas da passagem do tempo e do movimento da vida dos homens. Rio de Janeiro: Tese de doutorado. ECO-UFRJ.

LISSOVSKI, M. 1998. "Signo: Tigre. Ascendente: Lontra. História, fotografia e adivinhação em Walter Benjamin". O Percevejo. Rio de Janeiro: Uni-Rio, v. 6, n⿳⺈ 6, p. 92-106.

MACRON, E. 2000. "La Lumière blanche du passé. Lecture de La mémoire, l'histoire, l'oubli de Paul Ricoeur". Esprit. n 266-267, p. $16-31$, août., sept.

MORIN, E. 1997. "Le besoin d'une pensée complexe". In: CANDIDO MENDES (org.). Représentation et complexité. Rio de Janeiro: Edições Unesco/ISSC/EDUCAM, p. 85-96

. 1999. "Da necessidade de um pensamento complexo". In: MARTINS, F. (org.). Para navegar no século XXI. Porto Alegre: Sulina Edipucs, p. 19-42.

REVEL, N. 1998. Verbete "Épopée". In: CD-Rom Multimedia Encyclopadia Universalis. France S.A.

RICOEUR, P. 2000. “Aux origines de la mémoire, l'oubli de reserve". Esprit, n 266-267, p. 32 - 47, août., sept.

. 1985. Temps et récit. 3. Le temps raconté. Paris: Seuil. 2000. La mémoire, l'histoire, l'oubli. Paris: Seuil. 